\title{
Immunity of International Organisations against State Immunity: Selected Legal Problems
}

\author{
JerZy MenKes* \\ Anna Kociolek-Pęrsa**
}

\begin{abstract}
The aim of the study was to answer the question whether there are universal norms of customary international law governing the immunity of international organisations and their property and address the obstacles to the development of the UN Convention governing the immunity of international organisations. Through comparative legal analysis, the Author proves that state immunities result from international and national laws. In the case of immunities derived from international law, there are no universal standards defining the scope of the jurisdiction immunity of a state and its property. Jurisdictional immunity of international organisations has as its only source international law (many states also regulate the issue in their domestic law). The study showed that international regulations move in contradictory directions: as regards the states, there is a move away from absolute immunity, while for international organisations the expansion of the catalogue of authorized immunity and its scope is observed.
\end{abstract}

Keywords: immunity of a state and its property; immunity of international organisations and their property; international organisations; jurisdictional immunity; customary international law

\section{INTRODUCTION}

The goal of this legal analysis is a review of the institution of 'immunity of an international organisation' in functional dimension. Immunity of an international organisation is the normative groundwork for one of the three regimes of international immunities in the catalogue - state immunity, head of state and member of government immunity, and diplomatic immunity. I, therefore, extract a part from the whole for this analysis, but the extraction is incomplete and inconsistent. What connects the types of immunities is their effect, the result of implementation. They differ, among other reasons, in origin and function. Immunity of an international organisation has no past and has not been shaped, unlike state immunity, by a historical process, but is the result of a known institution (state immunity) being adapted for new needs. A well-known institution was then 'extracted' from its historical and functional context and, after slight modification, used to fulfil completely different social needs. The difference: having or not having roots is not decisive, however, that is essential for presenting discussing research problem. That difference is an idea and the fundamental of main research problem. The key is the difference in the subject of authorisation and the function between the immunity of an international organisation and state immunity, as well as the function-goal of the conferred immunity. The beneficiary of state immunity is the very state. State immunity protects the state and is a protective umbrella above it. The real beneficiaries of immunity of an international organisation are its members in a way and in many cases also other members of the international community.

* Professor, Collegium of World Economy, Warsaw School of Economics. E-mail: menkes. jerzy@gmail.com

** The Faculty of Civil Safety Engineering, The Main School of Fire Service, Warsaw, Poland. E-mail: annakociolek.peksa@gmail.com 
Immunity of an international organisation protects its members - it is the umbrella above them. State immunity serves the subject, it ensures inequality of treatment. Evidently, this inequality is desirable by the international community (otherwise international state immunity wouldn't exist), for by this, sui generis 'iron letter' states are encouraged to go beyond their own territories by giving them a warranty of safety. Each state and international society as a whole says to a state one can go outside without fear that infringing the law will put you in front of a tribunal in a place where one may commit a legally forbidden act or where one would bear its consequences. The message is clear: respect of the law will not be carried out in the universally accepted legal regime. This is obviously not identical with acceptance of breaking the law - immunity does not exempt from the obligation to respect the law but merely sets aside the possibility of a court execution of a law towards an infringing state in a third country.

State immunity deactivates territorial jurisdiction (outside of its borders). Both the states and the international community, however, have at their disposal other instruments (apart from those excluded or deactivated by immunity) for encouraging other states to respect the law and other regimes of action in case of infringement of the law. It is sufficient to indicate the benefits that a state respectful of the law will have in international circulation on one hand, and the refusal to confer such benefits as a consequence of infringement of the law on the other hand, to make it obvious that the immunity does not encourage neglect of the law and neither does it balance the negative consequences of infringement (from the concerned state's standpoint). International organisation immunity is at the service of everybody, it ensures equality and protects each member of the organisation and all of them as a whole against the potential to influence any of them through instruments of law in order to obtain unilateral benefits. An international organisation is not exempted from the duty to respect the law. State and international organisation immunities also elicit different final outcomes. A state making use of its immunity outside of its borders is not entitled to immunity within its own territory and takes full legal responsibility within the territory demarcated by its own borders. An international organisation making use of its immunity is not legally responsible anywhere. State immunity extends towards the territorial jurisdiction of another/other states; organisation immunity extends towards any jurisdiction (national or international).

\section{FIELD OF STUDY}

Jurisdictional immunities of the subjects of international law are institutions created as a result of multiple splits of immunity of sovereign-state into institutions, ${ }^{1}$ out of which, some have encompassed inner relationships and some have covered the outside aspect of the functioning of a state-its international relations. ${ }^{2}$ In practice, the norm of national law, jurisdictional immunity of a sovereign-state (acknowledged by national legal regimes), coveres the range of subjects, exterior to the sovereign and independent from it but is

1 Tak, et al (2004), see also Hanrahan (2005).

2 At the source there was diversified practice, such as the conflict preceding the British Act Preserving the Privileges of Ambassadors from 1708 (the act became an international model and was repeated, among others, in the American regulation from 1790); see also, the entry 'extraterritoriality', $<$ http://www.britannica.com/EBchecked/topic/199129/extraterritoriality> accessed 31 July 2017. 
considered equal in the eyes of the law, ${ }^{3}$ that resulted from the appearance of the sovereign in international circulation, ${ }^{4}$ and, as a consequence, this norm become (also) a norm of international law. ${ }^{5}$ In order to justify the immunities, the concepts of personal or functional exteriority were conjured. However, it can be simply stated, and this is exclusively decisive in the Westphalian order, that jurisdictional immunity in international legal circulation is coupled with the sovereignty and equality of the state. The essence of the sovereignty, of being a sovereign, is the lack of subordination to any other authority, this is not identical to a lack of subordination towards the law. The execution of jurisdiction always means execution authority, or supremacy. ${ }^{6}$ Jurisdictional immunity $^{7}$ is then understood in the large sense, as a lack of subordination to an external jurisdiction, ${ }^{8}$ 'exemption from the application or jurisdiction of local law or tribunals', ${ }^{9}$ 'immunity of a foreign sovereign, its agents, and its instrumentalities from litigation in U.S. courts' ${ }^{10}$ and the jurisdiction of authority of another subject. ${ }^{11}$ This rule may be expressed by the classic sentence, par in parem non habet imperium. ${ }^{12}$

${ }^{3}$ For a justification of the concept of absolute immunity, see the opinion of US Supreme Court Justice Marshall in The Schoonere Exchange v. McFadden, 11 U.S. 116 (1812) <http://supreme.justia. com/us/11/116/case.html $>$ accessed 31 July 2017, In the case of The Schoonere Exchange v. McFadden, the legal status of national ships (the status of the ships was evened up) was regulated differently from the status designed by the Brussels Convention from 1926; see Steiner, Vagts and Hongju Koh (1994) 757-62.

${ }^{4}$ For more, see: Second Report on Jurisdictional Immunities of States and their Property, by Sompong Sucharitkul, Special Rapporteur (pp. 214 and 215), <http://untreaty.un.org/ilc/publications/ yearbooks/Ybkvolumes(e)/ILC_1980_v2_p1_e.pdf > accessed 31 July 2017.

${ }_{5}^{5}$ It is generally agreed that the term was introduced to the International Law Dictionary at the end of the $18^{\text {th }}$ c. by G. F. von Martens. P. Ayraut is considered the father of the concept that was developed later by H. Grocjusz and S. von Pufendorf; see the definition of 'Extraterritoriality' in: Encyclopaedia Britannica, 2008, Encyclopaedia Britannica Online. <http://www.britannica.com/ EBchecked/topic/199129/extraterritoriality> accessed 31 July 2017.

${ }^{6}$ According to Cassese, immunity is not an expression of sovereignty but a limitation of sovereignty Cassese (2001) 91.

7 The entry 'immunity' is generally defined as: 'Any exemption from a duty, liability, or service of process', in: Black (1999).

8 For instance, the International Law Commission: 'Immunity' is a legal concept which can be expressed in terms of a jural relationship. Just as a 'right' is correlated to a corresponding 'duty' incumbent on another party, 'immunity' to which a person or party or State is entitled is correlated to 'no power' on the part of the corresponding authority. It signifies absence or lack of power, or necessity to withhold or suspend the exercise of such power. In other words, the expression 'immunity' connotes the non-existence of power or non-amenability to the jurisdiction of the national authorities of a territorial State', Black (1999) 204.

9 Merriam Webster's Dictionary of Law.

10 Entry 'foreign immunity', in: Black (1999).

11 From this understanding of jurisdiction of authority of another subject is excluded (at least since constitution and acknowledgement of the PCIJ jurisdiction) jurisdiction of international tribunals and courts, above all the ICJ and other specialized court organs. Also excluded in terms of jurisdiction are state-members of the organisation - executed by court organs of international organisations. ICC property constitutes a particular case.

12 See Rapport ILC (p. 159): 'The doctrine of State immunity is the result of an interplay of two fundamental principles of international law: the principle of territoriality and the principle of State personality, both being aspects of State sovereignty. Thus, State immunity is sometimes expressed in 
Other subjects of international law, IGOs, some NGOs such as the ICRC as well as states, are entitled to court immunity.

The roots of the institution are planted, and this is important for further considerations, in the 'national' status of the sovereign. The successor of this status was, and to a limited extent (such as no submission to the jurisdiction of a third country) still is, the state. Nevertheless, the sovereign lost immunity in the internal sphere. This occurred within the evolution of authority from the status of emperor-absolute ruler in Byzantium, who was 'the supreme judge, the head of administration and army' towards the order of the rule of law. The final point in the evolution dated to the end of the $18^{\text {th }}$ century and is symbolically expressed by the legend of the 'miller of Sanssouci'. ${ }^{13}$

In the case of international organisations, there are no historic connotations or justifications for the institution of immunity. Their juristic immunity at its core was and still is functional immunity. The immunity had its purpose to protect and fortify the independence of the international organisation in its internal actions from a state or states in case of an attempt to influence the organisation's actions in a mode unregulated by the law, that is, to undermine its independence. ${ }^{14}$ In 1931, the Italian Cessation Court proved this by stating in the case Profili v. International Institute of Agriculture that there was a lack of jurisdictional authority over the institute as a subject of international law as it was equipped with full autonomy in the internal sphere and an interdependent freedom from the authority of any state either territorial or personal supremacy. ${ }^{15}$

\section{CONTENT OF THE NORM}

Based on the praxis, it cannot be unequivocally stated whether jurisdictional absolute immunity has been narrowed to a limited extent; if new forms of state activity have not been covered; whether absolute immunity is classical ${ }^{16}$ or that what is classical is solely jure imperii ${ }^{17}$ actions. Two directions were equally justified were in the legislation, one to confer universal character to the practice sanctioning - the absolute jurisdictional immunity of the state and other subjects, and the other, the same measure with respect to limited immunity (with designed grounds for limitation). The matter of jurisdictional immunity of a state and its property was codified, as numerous states wished to sanction changes in their own domestic legal systems (US, ${ }^{18} \mathrm{UK}^{19}$ ); some wished to confer universal character to

the maxim par in parem imperium non habet', <http://untreaty.un.org/ilc/publications/yearbooks/ Ybkvolumes(e)/ILC_1978_v2_p2_e.pdf> accessed 31 July 2017.

13 More Parish (2010) 18 and following.

14 More: Rule of Law. International Immunity. Centre for Accountability of International Organisations, <http://www.caio-ch.org/RuleofLaw.html> accessed 31 July 2017.

15 Text: 'Annual Digest of Public International Law Case' 1929-1930, 'International Law Reports’, pp. 413-15.

${ }^{16}$ For analysis of the praxis, see: J. B. Tate (Acting Legal Adviser) in the document from $19^{\text {th }}$ of May 1952, called the 'Tate Letter', directed to P. B. Perlman (Acting Attorney General), <http:// caselaw.lp.findlaw.com/scripts/getcase.pl?court=US\&vol=425\&invol=682> accessed 31 July 2017.

17 The basis for this division is the doctrine of an 'act of State', which was analysed in the case Banco Nacional de Cuba v. Sabbatino, and earlier in the cases Underhill v. Hernandez and Oetjen v. Central Leather Co.

18 By the power of Section 1604 from the Foreign Sovereign Immunities Act of 1976.

19 According to Article 1 of the State Immunity Act of 1978. 
their own practice (Europe ${ }^{20}$ ), as there was/is conflict not only between the subjects of international law but also among other international actors over the content and range of international immunities (not only jurisdictional) and the catalogue of entitled immunities.

The conflict is characterized by its changing and constantly high growth, and it engagement to an important degree the interest of public opinion and concerns fundamental questions. On one hand, we deal partly with defence of the capacity to act in international relations - the law recognizing the value of functionalism (defence of immunity) and a law/ postulate invoking moral axiology, that is, equality before the law (the limitation of immunity at least).

In a nutshell may it can be said that limited immunity threatens circulation or absolute immunity threatens the law or values of law identified with the law such as equality and it is in unavoidability way goes to the dysfunctional of application of legal norms. ${ }^{21}$ It is doubtless, however, that the position resulting from accepting the United Nations Convention on Jurisdictional Immunities of States and Their Property ${ }^{22}$ and its lack of entry into force is particularly bad. The situation reveals both the lack of a universal regime of jurisdictional immunity of a state (and of other subjects of international law) and its property and an incapacity or at least serious difficulties in producing a universal standard. The protagonists of the legislative direction aimed at limited jurisdictional immunity reflected in the Convention, proved their strength and capacity without achieving victory, the entering into force of the Convention. What is more, none of the permanent members of the Security Council ratified the Convention and four out of the five only signed it. The main supporter of this direction of codification, the US did not do that. The US attitude may signify that it did not expect the Convention to enter into force or display a mindset to act unilaterally in reference to jurisdictional immunity of subjects of international law and their property or a larger, negative attitude towards progressive development and codification of international law in the institutionalized formula of the UN. ${ }^{23}$ At the same time, the failure of the Convention, which primarily codified the norms in force, did not create a legal vacuum.

\section{A. Precedents for a departure from absolute immunity}

It is undeniable that the idea of limitation of jurisdictional immunity of a state has not appeared as deus ex machina in the second half of the $20^{\text {th }}$ century. The absolute jurisdictional immunity of a state was already seriously undermined by Institut du Droit International during its session in Cambridge in $1895 .{ }^{24}$ The decisive argument in favour of

20 'Considering the fact, that in the international law there is a tendency to limit the number of cases [underlined by J. M.], in which the State can invoke the immunity against foreign courts', European Convention on State Immunity, Basel 16.05.1972.

${ }_{21}$ States ILC in points 12 and 13 of the Report (p. 159), <http://untreaty.un.org/ilc/publications/ yearbooks/Ybkvolumes(e)/ILC_1978_v2_p2_e.pdf> accessed 31 July 2017.

${ }^{22}$ Also: European Convention on State Immunity, Basel, 16. 05. 1972. $<$ https://www.coe.int/en/ web/conventions/full-list/-/conventions/treaty/074> accessed 31 July 2017.

23 Article 13 Charter of United Nations.

${ }^{24}$ See the limitations in Article 16 with reference to the general regulation: Règlement sur les immunités diplomatiques:

L'immunité de juridiction ne peut être invoqué:

$1^{\circ}$ En cas de poursuites exercées à raison d'engagements contractés par la personne exempte, non en sa qualité officielle ou privée, mais dans l'exercice d'une profession exercée par elle dans le pays concurremment avec ses fonctions diplomatiques; 
the change, however, culminated in the processes that took place in the $20^{\text {th }}$ century Socialist countries undertaking profit-oriented activity (production and trade) while aspiring to have both the benefits of the entitlements of a legal entity in trade and still be protected by jurisdictional immunity from any responsibility related with participation in trade. Nevertheless, these problems and phenomena, even if not entirely historic, are not the focus of public attention and they are not reasons to undermine norms composing jurisdictional immunity of the subjects of international law. The centre of attention constitutes cases of abuse of immunity, particularly diplomatic immunity, of a criminal nature with the participation of states, their diplomatic representatives, and of international organisations their officials. These events of various gravity but composing a unified image of abuse of the law ${ }^{25}$ encounter decisive resistance: scandals that came to be known as 'Oil for Food'26 and 'Sex for Food'27 - the protection against charges of 15 counts of rape against the son of a diplomat accredited in the US (1983); charges of sexual abuse by the UN High Commissioner for Refugees, Ruud Lubbers; ${ }^{28}$ the scale and high level of avoidance of financial commitments, such as debts, alimony and family benefits, ${ }^{29}$ the scale and gravity of this phenomenon is well illustrated by it becoming a topic of discussion during the Fourth World Conference on Women in 1995 in Beijing; ${ }^{30}$ the murder of policewoman Yvonne Fletcher, who was hit after gunfire from the window of Libya's embassy in London (1984); the real threat of accidents in traffic, well-illustrated by the nickname for the phenomenon - Diplomatenrennbahn (diplomats' race track) given to the highway near Bonn; fatal accidents caused by diplomats (Silviu Ionescu from Romania, Geuorgui Makharadze from Georgia, Andrei Knyazev from Russia, or Douglas Kent from the US) and disdain for the law as seen in unpaid parking fees. ${ }^{31}$

$2^{\circ}$ En matière d'actions réelles, y compris les actions possessoires, se rapportant à une chose, meuble ou immeuble, qui se trouve sur le territoire.

Elle subsiste, même en cas de contravention dangereuse pour l'ordre ou la sécurité publique ou de crime attentatoire à la sûreté de l'État, sans préjudice du droit pour le gouvernement territorial de prendre telles mesures conservatoires qu'il appartiendra (art. $6,3^{\circ}$ )

$<$ http://www.idi-iil.org/idiF/resolutionsF/1895_camb_01_fr.pdf.> accessed 31 July 2017.

25 For more, see: Flaherty (2003) also Parish (2010) 6 and following.

26 The abuses revealed in the Volcker Report directly charged UN General Secretary Kofi A. Annan, but also the entire organisation. The impulse that led to the revealing of the crimes was given by an investigation initiated in 2005 by Robert Morgenthau on highly ranked UN official Benon Sevan (a Cypriot citizen); for more, see: Anderson (2010).

27 This term is used for the series of crimes/scandals in which people hired by UNHCR in Sierra Leone, Liberia and Guinea perpetrated sex crimes (including rapes) on young women who were refugees in exchange for food.

28 For more, see: Goodenough (2010).

29 The case 'Barbara Elzohairy' became symbolic of this (she was the wife of an Egyptian representative to the UN) as was the case 'Fernandez v. Fernandez' (involving the divorce of a US citizen and a Mozambique representative to the UN).

30 For more, see the entry 'Diplomatic Immunity' in: West (2005).

31 In February 1995, the mayor of New York, Rudolph Giuliani, disclosed diplomatic arrears of 800000 USD. 


\section{B. Next steps}

If the first step (that is, the Convention) has been taken, even though we do not know whether it is a step towards a new, universal normative order as far as immunity is concerned or towards the unveiling and deepening of differences in legal standards among states, then regulation defined by subjects and needs must follow. The subject of public international law, other than states, such as IGOs and NGOs, need codification of their correspondent jurisdictional immunities and for their property even more than states. ${ }^{32}$ They also need codification of other immunities ${ }^{33}$ as well as an answer to the question of whether their jurisdictional immunity (but not only in this instance) can be larger than the jurisdictional immunity of a state. The scale of this challenge, not only for every state but also for the entire international community and each international organisation, is decided by the number of active international organisations (in every state ${ }^{34}$ ) and the dynamics of the process of granting immunity, including jurisdictionally, to the following organisations. ${ }^{35}$ Nevertheless, these very significant problems and challenges do not exhaust the topic of the study. I also am intenting to examine the existence of universal norms in the international law praxis that regulate the matter of immunity of international organisations and their property, with the basis in repetitive regulations in individual contracts. ${ }^{36}$

\section{Thesis}

The thesis of the present research is the lack of universal norms of international law praxis, regulating jurisdictional immunity of a state and its property, the fact of annihilating previously existing ones by modification of factual states and the organic inability to work out a universal regulation in reference to each international organisation. This organic inability results from non-homogeneity of the 'IO' category and appears even in subcategories: IGOs, while entitled by jurisdictional immunity are also organisations devoid of stricte international character (such as INTERPOL), but most of all, ICRC-NGO. The author has a basic doubt whether the initial statement of the Convention's preamble can be applied with respect to international organisations: 'Considering that the jurisdictional immunities of States and their property are generally accepted as a principle of customary

32 For convergent opinions, see Gaillard and Pingel-Lenuzza (2002) 1-15.

33 In relation to ILC states, correspondent codification work is conducted.

34 It is estimated that in the US, there are 75 international organisations entitled under the International Organisations Immunities Act (IOIA), among which we find well-known organisations such as NZ System and the ICRC, but also more 'exotic' ones such as the International Commission of Pacific Halibut, Inter-American Tropical Tuna Commission and the Global Fund to Fight AIDS, Tuberculosis and Malaria. Around 25000 international officials live and work in Geneva, out of which over $60 \%$ are hired on short-term contracts (3-6 months).

35 The status of INTERPOL is a good illustration: first, President Reagan declared it a public international organisation (Executive Order No. 12425 from 16.06.1983), followed by President Clinton, who exempted it from customs fees and granted it the right of tax return (Executive Order No. 12971 from 15. 09. 1995), and last, (17.12.2009), President Obama cleared it from all limitations under IOIA. In this trend to extend the list of organisations entitled under IOIA, there is no difference between Democrat or Republican administrations.

${ }^{36}$ In the case of the states, the Draft Declarations on the Rights and Duties of States from 1949 confirmed it in Article 2 ('Every State has the right to exercise jurisdiction over its territory and over all persons and things therein, subject to the immunities recognized by international law'), $<\mathrm{http} / / /$ untreaty.un.org/ilc/texts/instruments/english/commentaries/2_1_1949.pdf> accessed 31 July 2017. 
international law'; that international organisations and their property are and should be entitled to jurisdictional immunity (before domestic courts) and if the international community would be inclined to accept such a norm by acknowledging the immunity of every organisation within a formally unified subset of IGOs extended to other organisations - beneficiaries of the same status ad casum. What would be the content of immunity exceptions in reference to the IOs and whether analogically, a general demarcation of its range as well as resignation from such demarcation is possible in the case of the future codification.

\section{JURISDICTIONAL IMMUNITY OF AN INTERNATIONAL ORGANISATION, LEGAL STATE, RECONSTRUCTION OF THE NORM}

In the situation of a lack of abstract and general norms which determine the content of the jurisdictional immunity of IOs, ${ }^{37}$ an exclusively ad casum examination is possible, by invoking regulations made in response to the needs of particular organisations ${ }^{38}$ followed by verification or revocation of the hypothesis assuming the existence of the model. Without returning to the past more than is necessary, it is important to indicate that in Section 2 of the Convention on the Privileges and Immunities of the United Nations, 'The United Nations, its property and assets wherever located and by whomsoever held, shall enjoy immunity from every form of legal process except insofar as in any particular case it has expressly waived its immunity. It is, however, understood that no waiver of immunity shall extend to any measure of execution'. Similarly, in reference to the jurisdictional immunity of specialised agencies, Article III of the Convention on the Privileges and Immunities of the Specialized Agencies states: 'The specialized agencies, their property and assets, wherever located and by whomsoever held, shall enjoy immunity from every form of legal process except insofar as in any particular case they have expressly waived their immunity', as the norm was repeated: '2. The United Nations, its property and assets wherever located and by whomsoever held, shall enjoy immunity from every form of legal process except insofar as in any particular case it has expressly waived its immunity. It is, however, understood that no waiver of immunity shall extend to any measure of execution'.

Obviously, in the case of breaking the unified, universal legal regime of the legal praxis of absolute state jurisdictional immunity as a result, decisively, of US actions, it is indispensable to examine the US position towards IO jurisdictional immunity. The examination is initiated by the statement that the Convention on the Privileges and Immunities of the United Nations entered into force in the US (only) on the $29^{\text {th }}$ of April $1970 .{ }^{39}$ Leaving aside, irrelevant in this case (and much larger), the question of the US attitude towards multilateral treaties and the range of jurisdictional immunity based on which the UN was privileged in the US, the most essential fact would be that the US acknowledged the UN's absolute immunity already after the date by which through the 'Tate Letter' rejected the right of a state to be privileged by such (absolute) immunity. As far as the Convention on the Privileges and Immunities of the Specialized Agencies of the UN is concerned, the US without being a party to it, deemed it necessary to file on the $8^{\text {th }}$ of July 1975, a declaration referring to a GDR government declaration, derivative of the

37 For more, see: Menkes and Wasilkowski (2010) 240-43.

38 Immunities and privileges are granted to organisations and defined by bilateral or multilateral contracts or by unilateral acts by states or international organisations.

39 See: <http://www.state.gov/documents/organisation/143863.pdf> accessed 31 July 2017. 
accession of this country to the Convention. This Declaration also does not seem to discredit the range of the absolute jurisdictional immunity of specialized agencies. ${ }^{40}$ The Convention on the Safety of United Nations and Associated Personnel was signed by the US on the $19^{\text {th }}$ of December 1994 and despite the lack of ratification of the Convention, the US did not raise any objections to its Article 6, Paragraph 1, on such a significant matter.

This perpective is important of the accepting by the US, however, but the decisive character has the regulation comprised in the United States International Organizations Immunities Act (IOIA) from the 29th of December 1945, according to which '(b) International organizations, their property and their assets, wherever located, and by whomsoever held, shall enjoy the same immunity from suit and every form of judicial process as is enjoyed by foreign governments, except to the extent that such organizations may expressly waive their immunity for the purpose of any proceedings or by the terms of any contract'. It is without doubt that in 1945, in assigning jurisdictional immunity to international organisations 'on the same bases as benefit the states', signified the US was accrediting absolute immunity. It is also doubtless that the Foreign Sovereign Immunities Act (FSIA) from 1976 modified, to a limited extent, the range of the immunity of foreign states before American courts. Such a change in the range of jurisdictional immunity of a state and its property, however, does not automatically lead to a change to the range of jurisdictional immunity of an international organisation and its property as set forth under IOIA. The (US) legislature was familiar with the range of immunity as defined by IOIA and as a result, the range of immunity for a state and its property, and was able, while enacting FSIA, to make amendments to IOIA, to limit by rule the range of jurisdictional immunity accredited by the power of IOIA to international organisations to one accredited to a state. Potential doubts result from the modus operandi of the US legislature as it was applied in 1945.

In order to define the content of the jurisdictional immunity of an international organisation, the construct was used of an empty form of a legal provision remanding to a well-known and severe provision defining the content of state jurisdictional immunity, which had, in that time, a series of advantages.

- accelerated regulation needed on US territory (considered future and in the uncertain event of an international convention);

- by remanding to a well-known and precise provision, it simplified the application of the law and prevented possible difficulties or controversial judicature;

- it unveiled the ratio legis of the legislature, which was to ensure unified treatment for all states and international organisations as far as jurisdictional immunity goes.

The price to be paid, however, came after 1976, despite the benefits obtained in 1945 , is uncertainty with reference to the influence of the range of jurisdictional immunity of a state as determined by FSIA on the jurisdictional immunity of an international organisation as determined by IOIA. ${ }^{41}$ The ratio legis of the act from 1945 would speak to limitation of the immunity, a departure from absolute immunity, in good practice. However, the matter of a referral after the loss of binding force of the provision pertaining to the referral is regulated

40 See: A declaration relating to the declaration made upon accession by the German Democratic Republic concerning application to Berlin (West). Registered ex officio on 8 July 1975, http://treaties. un.org/doc/Publication/UNTS/Volume\%20973/volume-973-A-521-English.pdf.

41 It is confirmed by controversies around judicature in American courts, for instance, in the case of Oss Nakalva v. European Space Agancy or Atkinson v. Inter-American Development Bank; for more, see: Hardcastle (2010). 
in the introductory provisions, with the awareness that, on the one hand, it would be difficult for a repealed provision to be binding on the referral while, on the other hand, the legal grounds to automatically transfer the referral to the new provision are missing. The abovementioned desired standard of carefulness required in domestic relations should be even higher in international relations when there are no grounds to require the external subject to follow the changes in domestic law. ${ }^{42}$ Additionally, the doctrine of the 'act of State $^{\prime 3}$ that constitutes the base for the limitation of state jurisdictional immunity cannot be simply transferred to international organisations. While in the case of the states, "trade activity' (Section 1603 FSIA) has generally the character of an act jure gestionis, it is certainly not the case generally for IOs. ${ }^{44}$

These regulations (both, the American blanket referral and the UN Convention) create a common international standard that allows us to state the existence of a universal norm of legal praxis regulating jurisdictional immunity of international organisations.

Universality of the norm is confirmed by the regulations in the contracts shaping the legal status of regional organisations; particularly in situations when, as parties to these contracts, appear states standing for rejection of absolute jurisdictional immunity of the state. Such is the case of the European Council, European Union and NATO:

- European Council. The legal basis for the immunity is Article 3 of the General Agreement on Privileges and Immunities of the European Council from the $2^{\text {nd }}$ of September 1949: 'The Council, its property and assets, wherever located and by whomsoever held, shall enjoy immunity from every form of legal process except insofar as in any particular case, the Committee of Ministers has expressly authorized the waiver of this immunity.'

- European Union. Immunity is confirmed by the Protocol on Privileges and Immunities of European Communities from $8^{\text {th }}$ of April 1965;

- NATO. According Article 5 of the Agreement on the Status of the North Atlantic Treaty Organisation, national representatives and international staff, from the $20^{\text {th }}$ of September 1951: 'The Organisation, its property and assets, wherever located and by whomsoever held, shall enjoy immunity from every form of legal process except insofar as in any particular case the Chairman of the Council Deputies, acting on behalf of the Organisation, may expressly authorize the waiver of this immunity'.

In reference to the jurisdictional immunity of international organisations and organs, not only 'classical' organisations, but larger, 'international institutions', he existence of a net of singular contracts can be confirmed and their coherent resolutions create in the matter, the standard of the absolute jurisdictional immunity of the international organisation and its property - the state of the universal legal praxis. This conclusion is confirmed also by the coherent standpoint of the doctrine. ${ }^{45}$

\section{FINAL REMARKS}

To sum up, it may be stated that in the case of state immunity, there is a question of whether the immunities are grounded in international law and in domestic law. In reference to state immunities grounded in international law, there is no universal norm defining the range of

42 To what extent the legal state is haywire can be seen in the Diplomatic and Consular Privileges and Immunities from Criminal Jurisdiction Summary of Law Enforcement Aspects $<\mathrm{http} / / /$ www.state.gov/documents/organisation/20047.pdf> accessed 31 July 2017.

43 See: Lowenfeld (2002) 501 and following.

44 Illustrated by the case of the International Tin Council.

45 The Kirgis manual is representative of the situation, Kirgis (1993) 19-53. 
jurisdictional immunity or of property; the differences come not only from the gap between absolute and limited immunity but also from the range of the content of the limitation of the immunity. The creation of such norms of universal character also does not seem probable in the short-term or medium-term perspective.

Jurisdictional immunity of an international organisation has its sources exclusively in international law (while many states regulate the corresponding matter in domestic legislation). In the case of state immunity, it can be observed that an individualistic goal, protection by the law of the subject's interest or - at best - a transaction do ut des, that is, immunity of an international organisation serves the common interest, driven by 'communitarianism', decisions made by states abut granting them to international organisations are of an altruistic nature.

Simultaneously, in reference to a state, an argument for limitation of the immunities were and are abuses and the inability of a state to quickly and efficiently defend against such cases while a state entitlement to benefit from immunity is incontestable. This argument is invalid in the case of an international organisation. In the case of an international organisation, somehow 'imperceptibly' by small steps, the immunity has been extended over organisations with a dubious right to such privileged status. On the other hand, agreeing that the differences between the range of the conferred jurisdictional immunity of a state and its property should not be maintained as compared with international organisations, to the detriment of the state, then it is impossible to define the range of the content of limitations for the set of all the IOs and even for the subset of IGOs.

In spite of easy and spectacular enunciations, jurisdictional immunity as the subject of international law isn't fas nor ne fas. It is morally neutral; it is good because it is in force. It is impossible to put jurisdictional immunity in international relations under a judgment from the moral axiology standpoint, but it is necessary to build it in, make ties with l'ordre public. The state is exempt from duties by jurisdictional immunity only before a foreign court but it cannot take advantage or invoke the immunity before its 'own' domestic court. This allows it to be stated that jurisdictional immunity protects from a complaint exclusively before a foreign state. The subject legitimized to file a complaint can do so before the state's court (in this sense, jurisdictional immunity can be considered to be a procedural norm). The legal and factual state changes in reference to IOs, ${ }^{46}$ which do not possess courts (in this understanding); in their case, the lack of fori $^{47}$ results in the lack of actio. ${ }^{48}$

46 According to Martin Nerisky, spokesman for UN General Secretary Ban Ki-moon, enunciating on the Ruud Lubbers' case: 'As a general principle, I think you are aware of the general immunity that exists, [...] I am not talking about specific cases or specific areas, but as a general rule', quote from P. Goodenough (2010).

47 This complaint was expressed by Cynthia Brzak (in the case of Ruud Lubbers) in a letter to President Obama: 'Since the United Nations internal justice system is not independent or credible, the use of diplomatic immunity to prevent U.N. staff access to national legal systems is morally repugnant and inconsistent with human rights norms, [...] Moreover, many in the legal field also believe it to be unconstitutional', quote from Goodenough (2010).

48 This opinion was shared by Nasr Ishak, chairman of UNHCR staff council, and his standpoint had strong grounds in a report by the UN Office of Internal Oversight Service (OIOS), which was pressured to stop publication of the report (Francis Montil, former deputy director of the United Nations' internal investigation arm, quoted a high-ranking official under former UN General Secretary Kofi A. Annan: ' $[\ldots]$ that the complainant was an American woman, and therefore a neurotic attentionseeker who was no doubt exaggerating the incident'. 


\section{LITERATURE}

Anderson, Kenneth, 'Legal Accountability of International Organisations and Their Agents' (2010) December $28^{\text {th }}<$ http://opiniojuris.org/2010/09/16/legal-accountability-of-internationalorganizations-and-their-agents/> accessed 31 July 2017.

Black's Law Dictionary, (Garner, Brian ed, West Group 1999).

Böhre, Vincent, von Dewall, Sophia, Middel, Ingeborg, Steer, Cassandra, 'The (Non-) Application of International Law by the ILO Administrative Tribunal: possible legal avenues for establishing responsibility' (2004) July Amsterdam International Law Clinic <http://www.iowatch.org/legal/ amsterdam.pdf $>$ accessed 31 July 2017.

Cassese, Antonio, International Law (OUP 2001)

Flaherty, Edward, 'The Abuse of Functional Immunity Party Almost Over Last chance, last call?' (2003) 620, UN Special 2003 Archives.

Gaillard, Emmanuel and Pingel-Lenuzza, Isabelle 'International Organisations and Immunity from Jurisdiction: to restrict or to bypass' (2002) 1 International \& Comparative Law Quarterly 1-15.

Goodenough, Partick 'U.N. Employees Seek U.S. Supreme Court Ruling on Immunity for Top Officials' Thursday, March 04, 2010, < http://www.cnsnews.com/news/article/un-employees-seekus-supreme-court-ruling-immunity-top-officials> accessed 31 July 2017.

Hanrahan, Nick, 'A History of Diplomatic Immunity and the Development of International Organisations' (2005) 1 CAIO Intern Papers <http://www.caio-ch.org/reforms/Intern_Paper_I. pdf $>$ accessed 31 July 2017.

Hardcastle, Melanie, 'Immunity of International Organisations' (2010) 18 Aug, embassylaw.com $<$ http://embassylaw.com/2010/08/18\#0818-esa-iorg> accessed 31 July 2017.

Kirgis, Frederic L. Jr., International Organisations in their legal Setting (West Academic Publishing 1993).

Lowenfeld, Andreas, International litigation and arbitration (West Academic Publishing 2002).

Menkes, Jerzy and Wasilkowski, Andrzej, Organizacje międzynarodowe. Prawo instytucjonalne (International organisations. Law concerning institutions related to the functioning of international organizations) (Wolters Kluwer 2010).

Parish, Matthew, 'An Essay on the Accountability of International Organisations' (2010) 7 International Organisations Law Review 277 - 342.

Steiner, Henry, Vagts, Detlev, Hongju Koh, Harold, Transnational legal Problems. Materials and Texts ( $4^{\text {th }}$ edition, The Foundation Press, 1994)

West's Encyclopedia of American Law 2005, <http://www.encyclopedia.com/doc/1G2-3437701403. html> accessed 31 July 2017. 